\title{
Identifying Drivers of Organic Decertification: An Analysis of Fruit and Vegetable Farmers
}

\author{
Ariana P. Torres ${ }^{1,3}$ \\ Department of Horticulture \& Landscape Architecture and Agricultural \\ Economics, Purdue University, 625 Agriculture Mall Drive, West Lafayette, \\ IN 47907
}

Maria I. Marshall ${ }^{2}$
Department of Agricultural Economics, Purdue University, 403 W. State
Street, West Lafayette, IN 47907

Additional index words. market access, organic certification, farmers' perceptions, price premiums

\begin{abstract}
Little is known about the drivers of organic decertification and it is unclear what production practices farmers adopt after decertification. This article investigated how farm demographics and characteristics, sources of information, and perceptions influence a farmer's decision to decertify. The data for this article were from a 2012 webbased survey of fruit and vegetable farmers that were part of the Food Industry MarketMaker database. We used a robust probit regression to identify the drivers of organic decertification of fruit and vegetable farmers in the U.S. Demographics; farm's characteristics, sources of information, and farmer's perceptions were key factors influencing the decision to decertify. Finding useful information from price reporting services and certifiers decreased the probability to decertify. On the other hand, farmers located in the Midwest, those selling vegetables, and those perceiving the organic certification process as a barrier were more likely to decertify.
\end{abstract}

The total dollars of sales of organic certified foods have steadily increased over the last decade. The 2014 U.S. Department of Agriculture (USDA) organic survey report showed that fruits and vegetables remain the top two sectors of organic food sales, together accounting for $40 \%$ of dollar sales (USDA, 2015). This growth was a response of the increased demand from consumers and large food retailers pushing sales of certified products (Dimitri and Oberholtzer, 2009). However, USDA organic surveys illustrated that the number of certified farms and farmland have suffered important drawbacks. For example, the number of certified farms decreased by $12 \%$ from 14,540 in 2008 to 12,818 in 2015 (USDA-NASS, 2016). The growth in consumer demand and retailer interest suggested that economic opportunities existed for organic farms, yet farmers were either consolidating operations or those certified might have opted out of the certification program. This article aimed to understand why farmers who were USDA-certified organic producers chose to decertify.

Received for publication 18 Dec. 2017. Accepted for publication 5 Feb. 2018.

We thank the USDA-NIFA Organic Research and Education Initiative for funding the research.

${ }^{1}$ Assistant Professor.

${ }^{2}$ Professor.

${ }^{3}$ Corresponding author. E-mail: torres2@purdue. edu.
Most of the existing organic foods literature focused on investigating what motivated (or not) farmers to certify organic. Access to markets, price premiums, environmental concerns, and philosophical beliefs were the main drivers of organic certification (Burton et al., 1999; Constance and Choi, 2010; Padel, 2001; Torres et al., 2016; Veldstra et al., 2014; Wiegel, 2009; York et al., 2007). Understanding the organic certification drivers has been useful to develop federaland state-led initiatives to increase organic production. Although studying the drivers of organic certification was crucial to expand the supply of organic foods, understanding why farmers decertified and helping them remain certified could be as impactful to meet the organic goals.

We know little about the drivers of organic decertification. Only a few studies have addressed the motivations of farmers to decertify and most of them focused on farmers from California or Europe. Regulatory, market, and production issues were reported as major drivers of organic decertification among farmers who reverted to conventional practices (Klonsky and Smith, 2002; Läpple, 2010; Sahm et al., 2013; Sierra et al., 2008). Moreover, Sierra et al. (2008) cited personal issues as key constraints to maintaining certification among decertified farmers who kept using organic practices. Family and labor health were the top two personal issues that motivated decertified farmers to remain committed to organic farming. Although California agriculture captures most of the certified organic food production, there are important organic industries in other states that are likely to face different challenges.

It is unclear what production practices farmers adopted after decertification. For instance, farmers may have switched to conventional systems or remained using organic practices without the use of the certified label (Sierra et al., 2008). Whether decertified farmers kept farming organically or not may suggest the existence of different constraints toward organic certification. For instance, decertified farmers who remained farming organically may have felt aligned with the philosophy of organic agriculture but opposed the corporate organic market (Veldstra et al., 2014). It is also possible that farmers selling locally were able to build trust relationships that motivated them to substitute the certification label and helped them overcome certification costs (Torres et al., 2016). Or, it may be that certification cost was higher than the value they generated in the marketplace (Dimitri and Oberholtzer, 2008). Farmers who switched to conventional agriculture may have faced the lack of market access or price premiums and decided to access wholesale markets without the organic label (Sierra et al., 2008).

This study contributed to the literature in two ways. First, we identified the main factors driving organic decertification of fruit and vegetable farmers in the United States using a unique data set of farmers from 16 states that remained certified and those that dropped out of the certification program. Second, this study contributed to the literature by exploring the farming practices adopted by decertified farmers (whether they continued using organic practices or converted to conventional practices) and drew conclusions on their barriers to remain certified. Programs and policies aiming to increase organic certification can use our results to lower decertification rates, which may be as effective as recruiting new farmers to certify. It is also important to understand how to better assist decertified farmers who switch to conventional agriculture and those that remain farming organically.

\section{Organic Certification}

Organic certified farmers are required to follow the National Organic Program (NOP) rules and regulations for the production, handling, and labeling of certified foods. Farmers can be certified by a private, state, or foreign accredited agency, to ensure that products meet all NOP standards. Depending on the type and size of the operation, organic certification may be a significant expense for farmers. Certification fees include application, annual renewal, inspection, and annual assessment fees. After a 3-year transition period of following NOP standards, operations can sell and label their products using the USDA organic label. By using the organic seal, farmers can market their produce as organic and capture organic price premiums. The decision to certify is highly correlated 
with farmers' expectations that price premiums will offset the cost of certification and potential yield losses (Dimitri and Oberholtzer, 2009).

Federal and local governments have created various initiatives to support farmers' adoption of organic certification. For instance, the previous Agriculture Secretary, Tom Vilsack, invested nearly \$261 million in 2009-16 in research to support the growth and economic viability of the organic industry (USDA, 2016). These initiatives aimed to generate science-based information and provided economic, marketing, and production information to support the profitability of certified farmers or those interested in certifying. At the state level, cost-sharing programs have spent roughly $\$ 11$ million to assist farmers with up to $75 \%$ of their certification costs (USDA, 2016).

The USDA has conducted organic surveys to record the values of certified acreage, operations, and sales. Although the total dollar sales of organic foods increased from $\$ 3.2$ billion in 2008 to $\$ 6.2$ billion in 2015 , the number of organic farms has decreased (USDA-NASS, 2016). For example, the number of certified farms decreased by $12 \%$ from 14,540 in 2008 to 12,818 in 2015 . One explanation may be that the consolidation of organic operations has decreased the number of farms to improve efficiency (yield) and respond to growing market niches (Blank and Thompson, 2004). We propose that another explanation for these trends may be that organic farmers decided to decertify because of economic, production, and market constraints that have not helped operations meet their profitability expectations.

\section{Organic Decertification}

The literature has mainly focused on understanding the drivers of organic certification; only a few studies have investigated farmers' motivations to decertify. One stream of the literature has studied California organic operations (Klonsky and Smith, 2002; Sierra et al., 2008; Strochlic and Sierra, 2007). Although California captures most of the U.S. organic certified agriculture, there are important opportunities for organic industries in other U.S. regions. Another stream of the decertification literature has focused on European farmers. For instance, Läpple (2010) found that Irish certified farmers tended to drop certification after 5 years, right after support payments to organic agriculture ended. It seems that organic farmers faced critical market barriers and struggle to ensure long-term profitability (Sahm et al., 2013).

Ward et al. (2004) found that access to organic price premiums was one of the major economic incentives to adopt organic certification. Price premiums could help farmers achieve higher profits and offset yield losses and higher production costs (Dimitri, 2012). However, organic markets could saturate because of an oversupply of certified products or abundance of cheaper imports (Greene et al., 2009). For instance, the latest
USDA organic price reports showed lower price premiums for organic grains, apples, strawberries, and carrots (USDA-ERS, 2016). The lack of access to organic price premiums or high-valued markets may have motivated farmers to decertify.

A study of California organic certified operations found that $20 \%$ of surveyed farmers dropped out the certification program (Sierra et al., 2008). The survey also investigated if decertified farmers exited farming entirely or decided to keep farming under other production practices. About 35\% of decertified farmers exited agriculture because of factors unrelated to organic farming and the other $65 \%$ remained farming. Of those decertified farmers who remained farming, 59\% reverted to conventional practices and $41 \%$ maintained organic practices. The same study cited regulatory, market, and production issues as main drivers to decertify among farmers who reverted to conventional agriculture. On the other hand, decertified farmers who maintained organic practices did not cite market barriers and rather reported that issues not related to organic farming motivated decertification (Sierra et al., 2008).

Farmers decertified because of farm characteristics and management issues (Sahm et al., 2013). In a study of California organic growers, Klonsky and Smith (2002) found that the probability to decertify was higher for smaller farmers and farmers growing vegetables. Their study also found that farmers growing a high diversity of crops tended to remain certified. Vegetable-only farmers may have decertified because of the high volatility and saturation in the organic vegetable industry (Klonsky and Smith, 2002).

We know little about what drives organic certified farmers to decertify and what production systems they adopt afterward. Decertified farmers may maintain organic practices but avoid the bureaucracy of the certification process and find enough economic incentives in local markets for their noncertified organic products. Another possibility is that larger certified operations may revert to conventional agriculture because of low or nonexistent price premiums in organic markets. More research is needed to investigate how decertified farmers fare after opting out of the certification program and what market channels they access to sell their produce. Understanding the main drivers of organic decertification is important for the longterm sustainability of organic agriculture. Our findings can help design research and extension programs that help certified farmers overcome these barriers and decrease the number of decertified operations.

\section{Materials and Methods}

Data collection. The data for this analysis came from a 2012 web-based survey of fruit and vegetable farmers who were part of the Food Industry MarketMaker database. The database provided us with 4312 mail addresses and 3015 e-mail addresses of growers located in 16 states (Alabama, Arkansas, District of Columbia, Florida, Georgia, Iowa, Illinois, Indiana, Kentucky, Michigan, Mississippi, Nebraska, New York, Ohio, Pennsylvania, and South Carolina). This database facilitated the access to directto-consumer (DTC) markets channels by connecting farmers and buyers. Thus, farmers in our sample tended to have small- and mediumsized operations and sell directly to consumers.

We conducted a web-based survey using a mixed-mode design. To increase participation rate, we included a two-dollar bill in the invitation letter and sent e-mail reminders with intervals of two weeks. We received 1559 farmer responses, an effective response rate $(36 \%)$ for similar online surveys (Dillman et al., 2014). The survey asked for farm characteristics, farmer's demographics, source of information, and beliefs and perceptions toward organic agriculture and certification. We also asked farmers the percentage of their farm that was conventional, certified organic, transitioning to organic, or using organic practices but not certified.

The subsample focused on for the study included 234 farmers. Of them, 64\% farmers were organic certified (149) and $36 \%$ were certified but decided to drop out from certification (85). To obtain a clear analysis of the drivers of organic decertification, the subsample excluded conventional farmers and organic farmers who were never certified.

Model specification. We used a standard probit regression to assess the drivers of organic decertification. The probit estimated how farmer's demographics, farm characteristics, sources of information, and farmer's perceptions drove the decision to decertify. For instance, certified farmers selling through DTC market channels may have perceived that alternative labels (e.g., Certified Naturally Grown and Indiana Grown) were less costly or more effective at capturing price premiums. Alternatively, larger certified farmers selling wholesale may have perceived they needed the organic label to capture price premiums and decided to remain certified. The study also provided estimates of a robust probit regression. We used robust standard regressions to deliver valid statistical inferences in case the survey yielded variables that were independent but not identically distributed. The robust probit can also help address potential heteroscedasticity (Wooldridge, 2010).

The standard probit was based on an observed binary variable $y$ and latent continuous variable $y^{*}=x^{\prime} \beta+\mu$. Although $y^{*}$ was not observed, we were able to observe

$$
y=\left\{\begin{array}{l}
1 \text { if } y^{*}>0 \\
0 \text { if } y^{*} \leq 0
\end{array} .\right.
$$

Given the variables $y$ and $y^{*}$, we can estimate:

$$
\begin{aligned}
\operatorname{Pr}(y=1) & =\operatorname{Pr}\left(x^{\prime} \beta+\mu>0\right)=\operatorname{Pr}\left(-\mu<x^{\prime} \beta\right) \\
& =F\left(x^{\prime} \beta\right) .
\end{aligned}
$$


Equation [1] illustrates the standard probit regression. The dependent variable was the binary decision to decertify among organic certified farmers. We grouped producers in two categories. The first category was the group of farmers who were USDA organic certified or were in the 3-year transition period to certification. The second group was the group of farmers who were certified and dropped the certification program. Thus, the dependent variable decertified $=1$ if the farmer decertified and decertified $=0$ if the farmer was certified or in transition to certification at the moment of the survey.

$$
\begin{aligned}
\operatorname{Pr}(\text { decertified }= & 1 \mid X)=\Phi(X \beta) \\
= & \Phi\left(\beta_{0}+\operatorname{demog} \beta_{1}+\operatorname{farm} \beta_{2}\right. \\
& + \text { information } \beta_{3} \\
& \left.+ \text { perceptions } \beta_{4}\right),
\end{aligned}
$$

where $\Phi(\cdot)$ is the standard normal cumulative distribution function, $X=\left(1\right.$, dtc, $\left.X_{2}\right)$ is a vector of covariates, and $\beta=$ $\left(\beta_{0}, \beta_{1}^{\prime}, \beta_{2}^{\prime}, \beta_{3}^{\prime}, \beta_{4}^{\prime}\right)^{\prime}$ is a vector of unknown constants.

Table 1 illustrates the set of covariates in Eq. [1]. A correlation test performed to the set of covariates in Eq. [1] indicated the lack of correlation. The covariates demog corresponded to demographic factors such as educational attainment, gender, race, if the respondent farmed part-time, and farm location. The study grouped farmers in four geographic regions such as South, Delta, Northeast, and Midwest. The South region corresponded to operations located in Florida, Georgia, and South Carolina. The Delta region grouped farms located in Alabama, Arkansas, Mississippi, and Louisiana. Farms in the Northeast region were located in New York and Pennsylvania. Last, Midwest farms were located in Iowa, Illinois, Indiana, Michigan, Nebraska, Ohio, and Kentucky.

The set of variables farm illustrated farm characteristics. We categorized farm size as exempt, small, and medium according to their gross annual sales. We followed Torres et al. (2016) to base sale cutoffs for farm size categories. Exempt farmers reported sales less than $\$ 5,000$ in gross annual sales, small farms reported sales between $\$ 5,000$ and $\$ 50,000$, and medium and large farms were those with gross annual sales of more than $\$ 50,000$. Farm characteristics also included the number of crops, if the farmer grew vegetable crops, if the farmer used DTC market channels, the average distance to markets, the number of acres, if the farmer rented land, if the business structure of the farm was a sole proprietorship, the number of years farming, and the average hours per week the farmer worked on farm business.

The set of variables information included the sources of information that farmers found useful. The list of sources of information include price reporting services, directories of product buyers, university extension, farmers and growers' associations, organic certifiers, and wholesalers or retailers. We followed Constance and Choi (2010), Sierra et al. (2008), Walz (2004), and York et al. (2007) to analyze the farmers' attitudes and beliefs toward the organic industry. For example, the set of variables perceptions included farmers' attitudes and beliefs toward organic markets reliability, the riskiness of organic agriculture, the perception of organic as a diversification strategy, the uncertainty to obtain organic price premiums, and if the farmer supported the philosophy of organic farming. The index variable bcerti measured farmers' perceptions toward the process of organic certification. The use of an index helped minimize the number of explan-

\begin{tabular}{|c|c|}
\hline \multicolumn{2}{|l|}{$\begin{array}{l}\text { Variable } \\
\text { Dependent variable }\end{array}$} \\
\hline Decertified & $1=$ if farmer was certified but decided to no longer be certified organic or started the certification process but did not certify \\
\hline \multicolumn{2}{|r|}{ 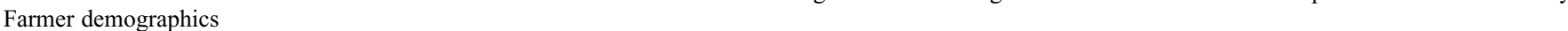 } \\
\hline College & $1=$ individual has college degree or postgraduate work \\
\hline Nonwhite & $1=$ if farmer is black, African American, American Indian, Asian, Multiracial, or other \\
\hline South region & $1=$ in Florida, Georgia, and South Carolina, 0 otherwise \\
\hline Delta region & $1=$ in Alabama, Arkansas, Mississippi, and Louisiana, 0 otherwise \\
\hline \multicolumn{2}{|l|}{ Farm characteristics } \\
\hline Exempt farm & $1=$ if annual gross sales less than $\$ 5,000$ \\
\hline Small farm & $1=$ if annual gross sales between $\$ 5,000$ and $\$ 50,000$ (reference group) \\
\hline Medium farm & $1=$ if annual gross sales larger than $\$ 50,000$. This group includes what is commonly defined as medium and large farms \\
\hline Number of crops & number of crops \\
\hline Vegetable grower & $1=$ if farmer grows vegetable crops \\
\hline Years farming & Number of years farming \\
\hline Hours on farm & average hours per week that farmer works on farm business \\
\hline \multicolumn{2}{|c|}{ Useful sources of information } \\
\hline Price reporting services & $1=$ if price reporting services is a useful source of information \\
\hline Directory of buyers & $1=$ if directories of product buyers is a useful source of information \\
\hline University extension & $1=$ if university extension is a useful source of information \\
\hline Farmers association & $1=$ if farmers and growers association are a useful source of information \\
\hline Certifiers & $1=$ if organic certifiers are a useful source of information \\
\hline Wholesalers & $1=$ if wholesalers or retailers are a useful source of information \\
\hline \multicolumn{2}{|l|}{ Farmer's perceptions } \\
\hline Organic is reliable & $1=$ if farmer somewhat or strongly believes that organic markets are reliable \\
\hline Transitioning is risky & $1=$ if farmer somewhat or strongly believes that transitioning to organic is risky \\
\hline Organic diversification & $1=$ if farmer somewhat or strongly believes that organic is a good way to diversify operations \\
\hline Uncertainty premium & $1=$ if farmer perceives that uncertainty in obtaining organic price premiums is a moderate or severe barrier \\
\hline
\end{tabular}
atory variables and the number of missing

Table 1. Categories and descriptions of the variables used to investigate the drivers of organic decertification among fruit and vegetable farmers of 16 states in the United States.

${ }^{\mathrm{z}} \mathrm{DTC}=$ direct-to-consumer. 
observations (Kim and Mueller, 1978). This index included farmer's perception that certification was a barrier due to loss of freedom, paperwork, cost of certification, interaction with the certifier, and lack of information. The index grouped the variables based on a 3-point Likert-like scale from not a barrier (1) to a severe barrier (3).

\section{Results}

Summary statistics. Table 2 provides the mean differences for all the variables used in the model, by type of producer. More than $63 \%$ of farmers in the sample had college or portion among certified farmers and those who decertified. Only $38 \%$ of farmers were female, with similar percentages for both certified and decertified growers. These results are consistent with Walz (2004), who found that women tend to be a minority among organic farmers.

There were significantly more decertified farmers $(56 \%)$ located in the Midwest region in states including Iowa, Illinois, Indiana, Michigan, Nebraska, Ohio, and Kentucky, when compared with certified farmers $(36 \%)$ $(P<0.01)$. The concentration of decertified farmers in the Midwest may be a response of farmers to the increased popularity of DTC outlets and initiatives to promote local markets. For instance, we found that a third of postgraduate education, with a similar pro-

Midwest decertified farmers sell directly to consumers, compared with only a fourth of certified farmers. On the other hand, certified farmers are concentrated in the Northeast region in states such as Pennsylvania and New York $(P<0.01)$. Guptill (2009) reported that organic certified agriculture is attractive to New York farmers and Dimitri and Greene (2002) illustrated that organic production in New York rated high compared with the rest of the country. High-volume and high-value markets in large population centers may be offering economic incentives to organic certified fruits and vegetables operations in the Northeast.

Less than a third of farmers in our sample operated part-time. Part-time farming was significantly more common among decertified farmers than their counterparts $(P<0.1)$. For instance, more than a third of decertified farmers responded that farming was their part-time job, whereas this was only true for less than a fourth of certified farmers. Our data showed that there were significantly more small farms that have decertified than their counterparts $(P<0.01)$. This finding is consistent with Constance and Choi (2010), who reported that organic operations tended to be smaller in size. Alternatively, there were significantly more medium (and large) farms that remained certified than their counterparts $(P<0.01)$. Table 2 shows that more than $50 \%$ of farms in our sample were medium

Table 2. Comparison of respondents of the Purdue 2012 survey of MarketMaker growers categorized by producer type (full sample, $N=234$; decertified farmers, $N=85$; certified farmers, $N=149$ ).

\begin{tabular}{|c|c|c|c|c|c|c|c|c|}
\hline \multirow[b]{2}{*}{ Variable } & \multicolumn{2}{|c|}{ Full sample } & \multicolumn{2}{|c|}{ Decertified } & & \multicolumn{2}{|c|}{ Certified } & \\
\hline & Mean & SD & Mean & SD & & Mean & SD & \\
\hline$\overline{\text { College }^{z}}$ & 0.63 & 0.48 & 0.60 & 0.49 & & 0.65 & 0.48 & \\
\hline Female & 0.38 & 0.49 & 0.39 & 0.49 & & 0.37 & 0.48 & \\
\hline Nonwhite & 0.06 & 0.24 & 0.05 & 0.22 & & 0.06 & 0.25 & \\
\hline South region & 0.12 & 0.33 & 0.11 & 0.31 & & 0.13 & 0.33 & \\
\hline Delta region & 0.04 & 0.20 & 0.05 & 0.21 & & 0.04 & 0.20 & \\
\hline Midwest region & 0.44 & 0.50 & 0.56 & 0.50 & $\mathrm{~A}^{\mathrm{y}}$ & 0.36 & 0.48 & B \\
\hline Northeast region & 0.35 & 0.48 & 0.22 & 0.42 & $\mathrm{~B}$ & 0.43 & 0.50 & A \\
\hline Part-time & 0.28 & 0.45 & 0.34 & 0.48 & A & 0.24 & 0.43 & B \\
\hline Exempt farm & 0.07 & 0.26 & 0.10 & 0.31 & & 0.06 & 0.23 & \\
\hline Small farm & 0.41 & 0.49 & 0.55 & 0.50 & A & 0.34 & 0.47 & B \\
\hline Medium farm & 0.52 & 0.50 & 0.35 & 0.48 & $\mathrm{~B}$ & 0.60 & 0.49 & A \\
\hline Number of crops & 23.40 & 13.78 & 22.65 & 13.89 & & 23.83 & 13.74 & \\
\hline Vegetable grower & 0.89 & 0.31 & 0.92 & 0.28 & & 0.88 & 0.33 & \\
\hline Direct-to-consumer markets & 0.94 & 0.24 & 0.92 & 0.28 & & 0.95 & 0.21 & \\
\hline Distance to markets & 38.30 & 60.71 & 28.92 & 40.18 & B & 43.52 & 69.14 & A \\
\hline Total land in acres & 364.64 & 830.08 & 399.24 & 983.13 & & 344.90 & 731.51 & \\
\hline Rent land & 0.37 & 0.48 & 0.35 & 0.48 & & 0.38 & 0.49 & \\
\hline Sole proprietorship & 0.50 & 0.50 & 0.58 & 0.50 & A & 0.46 & 0.50 & $\mathrm{~B}$ \\
\hline Years farming & 23.30 & 16.96 & 23.08 & 18.72 & & 23.43 & 15.94 & \\
\hline Hours on farm & 47.48 & 24.41 & 44.68 & 25.20 & & 49.07 & 23.89 & \\
\hline Price reporting services & 0.35 & 0.48 & 0.22 & 0.42 & B & 0.42 & 0.50 & A \\
\hline Directory of buyers & 0.26 & 0.44 & 0.23 & 0.43 & & 0.27 & 0.45 & \\
\hline University extension & 0.67 & 0.47 & 0.65 & 0.48 & & 0.69 & 0.47 & \\
\hline Farmers association & 0.63 & 0.48 & 0.61 & 0.49 & & 0.64 & 0.48 & \\
\hline Certifiers & 0.54 & 0.50 & 0.30 & 0.46 & $\mathrm{~B}$ & 0.68 & 0.47 & A \\
\hline Wholesalers & 0.53 & 0.50 & 0.46 & 0.50 & & 0.56 & 0.50 & \\
\hline Organic is reliable & 0.74 & 0.44 & 0.65 & 0.48 & $\mathrm{~B}$ & 0.79 & 0.41 & A \\
\hline Transitioning is risky & 0.29 & 0.46 & 0.31 & 0.46 & & 0.29 & 0.45 & \\
\hline Organic diversification & 0.62 & 0.49 & 0.58 & 0.50 & & 0.65 & 0.48 & \\
\hline Uncertainty premium & 0.64 & 0.48 & 0.63 & 0.49 & & 0.65 & 0.48 & \\
\hline Support philosophy & 0.90 & 0.30 & 0.87 & 0.34 & & 0.91 & 0.28 & \\
\hline Certification index & 1.60 & 0.40 & 1.77 & 0.39 & A & 1.51 & 0.38 & B \\
\hline
\end{tabular}

${ }_{\mathrm{z}}^{\mathrm{C}}$ The mean is the percentage of respondents with that attribute.

${ }^{y}$ Any two means within a row show the significant difference between the certified and decertified group at $P<0.1$ using Tukey's significant different test.
( $>\$ 50,000$ gross annual sales) and most of them remained certified $(60 \%)$, whereas only $35 \%$ of medium farms decided to decertify. Consistently, Sierra et al. (2008) found that decertification rates were smaller for larger operations.

The average distance to market for farmers in our sample was 39 miles. The data show that more decertified farmers sold their produce to markets closer to their operations than certified growers $(P<0.1)$. It may be that the lack of distribution channels has motivated growers sell directly to consumers (Sierra et al., 2008), where the certified label may not be a requirement to access price premiums. More than half of decertified growers were sole proprietors $(P<0.1)$. The sources of information that most farmers considered useful were university extension services and farmers' and growers' associations. Price reporting services were reported as significantly more useful by certified farmers $(42 \%)$ than their counterparts $(P<$ $0.01)$. Similarly, significantly more certified farmers $(68 \%)$ perceived that information from certifiers is useful $(P<0.01)$. About $74 \%$ of farmers in our sample believed that organic markets were reliable; and this was significantly higher for certified farmers (79\%) than their counterparts $(P<0.05)$. The perception that certification process as a barrier to certify was significantly higher among decertified farmers than their certified counterparts $(P<0.01)$.

We asked decertified farmers to rank the most important reasons to decertify. Following Sierra et al. (2008), we provided three broad barrier categories to farmers: market barriers, certification process barriers, and production barriers. Certification barriers was ranked as the most important barrier by $72 \%$ of decertified farmers, followed by market barriers $(23 \%)$ and production barriers $(5 \%)$.

The farming practices of decertified farmers. This study contributes to the literature by exploring the farming practices adopted by decertified farmers. The results provide empirical evidence that most decertified farmers remained growing organically and selling through DTC outlets. For instance, $72 \%$ of decertified farmers maintained organic practices, whereas only $16 \%$ of decertified farmers reverted to conventional agriculture and $12 \%$ of decertified producers reported growing under both conventional and organic practices. In other words, less than $30 \%$ of growers reverted their operation to conventional agriculture. In contrast, most of the decertified farmers in Sierra et al. (2008) reverted to conventional practices.

It is possible that farmers dropped out of certification because of the barriers of certification but decided to maintain organic practices as a strategy to obtain price premiums for locally- and organically grown produce. It is also possible that decertified farmers were "committed organic" farmers, who are defined as those invested in the philosophy of the organic movement (Darnhofer et al., 2005). The results also 
provide insight on the marketing practices of decertified operations. About 39\% of decertified farmers sold only through DTC markets, $7 \%$ sold only wholesale, and $54 \%$ sold through both DTC and wholesale markets. In other words, most decertified farmers used direct sales for their produce.

Regression results. The main contribution of this article is the empirical evidence of the main drivers of organic decertification of fruit and vegetable farmers in the United States. Table 3 displays the coefficients and marginal effects from the robust probit model. Although estimates and marginal effects were similar between the standard and robust probit regressions, this study used the robust results to provide conservative estimates and address potential heteroscedasticity. The results showed that demographics, farm characteristics, sources of information, and perceptions were key factors influencing the decision of certified farmers to drop the program.

There is evidence from the regression analysis that demographics variables are driving farmers' decision to opt out from the certification program. For instance, female farmers were $16 \%$ less likely to decertify than men $(P<0.01)$. An explanation is that women tend to have a greater affinity to organic agriculture (Parrott et al., 2006) because of their focus on the nutrition and health benefits for their families (Padel, 2001). These findings were consistent with Sierra et al. (2008) who found that fewer women tend to leave certification programs. Farmer's ethnicity and the decision to decertify seemed to be related. Farmers who identified themselves as black or African American, American Indian, Asian or Pacific Islander, or multiracial were $38 \%$ more likely to decertify when compared with white farmers $(P<0.05)$.

Results suggest that farm location was a significant driver for the farmers' decision to decertify organic. Farmers in the Midwest region were $14 \%$ more likely to decertify with respect to their Northeast counterparts $(P<0.01)$. Torres et al. (2016) reported that farmers located in Northeast states such as Pennsylvania and New York were more likely to adopt certification, which may be due to the existence of larger population centers offering access to high-value and high-volume markets. Other studies have also reported that organic agriculture tends to concentrate in areas where the demand and processing and distribution chains exist (Dimitri and Oberholtzer, 2009; Klonsky, 2000). The absence of numerous urban markets in the Midwest may be motivating farmers to sell locally, where the USDA organic label not

Table 3. Robust probit estimation results of the drivers to organic decertification (certified operations were uses as base with a coefficient of zero).

\begin{tabular}{|c|c|c|c|c|}
\hline & \multicolumn{4}{|c|}{ Robust probit } \\
\hline & Coefficient & SE & Marginal effect & \\
\hline College & 0.05 & 0.31 & 1.06 & \\
\hline Female & -0.78 & 0.30 & -15.81 & $* * *$ \\
\hline Nonwhite & 1.89 & 0.83 & 38.06 & $* *$ \\
\hline South region & 0.57 & 0.43 & 11.56 & \\
\hline Delta region & -1.43 & 0.78 & -28.71 & $*$ \\
\hline Midwest region & 0.72 & 0.34 & 14.44 & $* *$ \\
\hline Part-time & -0.66 & 0.41 & -13.20 & \\
\hline Exempt farm & 0.72 & 0.68 & 14.45 & \\
\hline Small farm & 0.33 & 0.37 & 6.63 & \\
\hline Number of crops & -0.01 & 0.01 & -0.22 & \\
\hline Vegetable grower & 1.47 & 0.60 & 29.54 & $* * *$ \\
\hline Direct-to-consumer markets & -2.89 & 0.79 & -58.25 & $* * *$ \\
\hline Distance to markets & -0.01 & 0.00 & -0.12 & $*$ \\
\hline Total land & 0.00 & 0.00 & 0.01 & $* *$ \\
\hline Rent land & -0.28 & 0.36 & -5.63 & \\
\hline Sole proprietorship & 0.45 & 0.31 & 9.12 & \\
\hline Years farming & -0.01 & 0.01 & -0.22 & \\
\hline Hours on farm & -0.01 & 0.01 & -0.26 & $*$ \\
\hline Price reporting services & -1.34 & 0.34 & -27.08 & $* * *$ \\
\hline Directory of buyers & -0.03 & 0.34 & -0.69 & \\
\hline University extension & -0.41 & 0.34 & -8.16 & \\
\hline Farmers association & 0.58 & 0.32 & 11.60 & $*$ \\
\hline Certifiers & -0.71 & 0.32 & -14.29 & $* *$ \\
\hline Wholesalers & -0.12 & 0.34 & -2.34 & \\
\hline Organic is reliable & -1.44 & 0.38 & -29.02 & $* * *$ \\
\hline Transitioning is risky & -1.22 & 0.39 & -24.58 & $* * *$ \\
\hline Organic diversification & 0.10 & 0.31 & 1.98 & \\
\hline Uncertainty premium & -0.30 & 0.34 & -6.06 & \\
\hline Support philosophy & -0.42 & 0.56 & -8.48 & \\
\hline Certification index & 1.31 & 0.43 & 26.43 & $* * *$ \\
\hline Constant & 2.51 & 1.55 & - & \\
\hline Number of observations & & & 145 & \\
\hline Probability $>\chi^{2}$ & & & 0.00 & \\
\hline Pseudo $R^{2}$ & & & 0.44 & \\
\hline Log likelihood & & & -52.31 & \\
\hline
\end{tabular}

Data Source: Purdue 2012 Survey of MarketMaker Growers.

$*,{ }^{* *},{ }^{* *}$ Significant at $P \leq 0.05,0.01$, or 0.001 , respectively. as necessary to obtain price premiums (Torres et al., 2016). On the other hand, farmers in the Delta region were $29 \%$ less likely to decertify. In our sample, farmers in Delta states such as Alabama, Arkansas, Mississippi, and Louisiana sold their produce to more distant markets. One explanation is that as farmers' distance to market increased, they relied on the USDA organic label to access price premiums. This is especially true as the results suggested that farmers located farther from their markets were less likely to decertify $(P<0.1)$.

Results from the robust probit suggested that farm management and farm characteristics were important factors driving the decision to decertify among certified farmers. Farmers selling vegetables were $30 \%$ more likely to decertify when compared with fruit growers $(P<0.05)$. Dimitri and Greene (2002) reported that smaller organic operations tend to grow mainly vegetables. Similarly, our sample suggested that operations growing vegetables had fewer acres and lower sales. It may be that farmers perceived organic certification as costly or risky among smaller operations growing vegetables. This is especially true as the markets for organic vegetables tended to become easily saturated and had a higher price volatility (Klonsky and Smith, 2002).

Surprisingly, farmers selling directly to consumers were $58 \%$ less likely to decertify $(P<0.01)$. An explanation may be that most of farms in our MarketMaker database were smaller or medium, who sold directly to consumers. These operations may be able to capture higher price premiums in local markets for their certified produce, especially if they sold through large value markets in urban centers.

Sources of information and farmer's perceptions toward organic agriculture influenced their decision to decertify. For instance, farmers were $27 \%(P<0.01)$ and $14 \%(P<0.01)$ less likely to decertify if they reported that information from price reporting services and organic certifiers were useful, respectively. An explanation is that price reporting services are generally available for large mainstream markets (e.g., wholesale); thus, farmers accessing these price reports may need to rely on the USDA organic label to access organic price premiums in wholesale markets. On the other hand, farmers who received useful information from other farmers were $12 \%$ more likely to decertify $(P<0.1)$. It is likely that building connections with other farmers may be helping producers access local markets, where there are enough economic incentives for noncertified products.

Farmers who perceived that organic markets are reliable and transitioning to organic is risky were $29 \%$ and $25 \%$ less likely to decertify, respectively $(P<0.01)$. Our data showed that farmers perceiving organic agriculture as risky tended to own larger operations, specialized in fewer crops, obtained information from certifiers, and sold through wholesale channels. Although these farmers may have perceived organic as risky, they seemed to have implemented strategies to 
manage risk and uncertainty (Hanson et al., 2004). Last, it seems that the certification process was a major barrier to remain certified. Farmers who perceived that certification was a barrier were $26 \%$ more likely to decertify $(P<0.01)$.

\section{Discussion and Conclusions}

The major contribution of this article is the empirical evidence of the drivers to organic decertification. Individual demographics, farm characteristics, sources of information, and perceptions regarding organic markets were key drivers of organic decertification. Understanding drivers of decertification could help the creation of initiatives that lower decertification rates and contribute to increased supply of organic foods. It could be that supporting farmers to remain certified may be as cost-effective as recruiting new farmers to the certification program to maintain, let alone, increasing organic production.

The results shed light on the influence of women in organic agriculture. Women were not only more likely to convert to organic agriculture (Padel, 2001) but also less likely to decertify after adopting organic certification. It may be that women may be more inclined to remain certified because of their attitudes and preferences toward healthy foods and environmentally friendly agriculture (Holt and Reed 2006). There has been also evidence in the literature that women tend to be more involved in the production of fruits and vegetables than other crops (Whatmore, 2016), which may motivate them to certify and remain certified as vegetables are the fastest growing segment of organic food sales.

Our results supported findings from Etmanski (2012), who reported that white non-Hispanic Americans has been the main racial and ethnic group leading the organic foods movement. Our results showed that nonwhite certified farmers were more likely to drop the certification program. It is likely that African American, Hispanics, and other minority farmers face greater barriers to remain certified, such lack of access to capital and price premiums. In our data, nonwhite growers reported on average lower revenues and perceived that organic markets were risky, which may be constraining their participation and success in the organic industry.

Farm location influenced the decision to decertify. The probability to decertify was higher for those farmers located in the Midwest and lower for those in the Delta region, when compared with operations in the Northeast region. The lack of numerous and large population centers in the Midwest may be pushing farmers to engage in local markets, where the USDA-certified label may not be a requirement to receive price premiums (Hinrichs, 2000). Thilmany et al. (2008) reported that consumers in local markets tended to prioritize origin of foods (local), trust relationships with farmers, and the impact of their expenditures on their community over the USDA organic label. On the other hand, farmers trying to reach farther markets via wholesalers may needed to remain certified to access price premiums as the grower-consumer relationship could not be straightforward. This is especially true as our results suggested that farmers located farther from their markets were less likely to decertify.

Information sources had a major influence on the farmer's decision to remain certified. The likelihood of decertifying decreased for farmers relying on certifiers and price reporting services and increased for those obtaining information from other farmers and farmers associations. It is likely that farmers relying on certifiers and price reporting services were those selling wholesale, where USDA organic labels were required to access price premiums. The data showed that farmers relying on other farmers tended to have smaller operations, sell locally, and perceived that receiving a price premium was a barrier. The literature has shown that farmers selling locally tend to form networks and relationships, which might have helped them access profitable local markets (Brown and Miller, 2008).

Social, attitudinal, and philosophical beliefs influenced farmers' motivation to adopt - or not - organic farming (Mzoughi, 2011; Veldstra et al., 2014; Torres et al., 2016). According to Veldstra et al. (2014), farmers were more likely to certify if their philosophical beliefs aligned to those of organic agriculture. Dimitri (2012) and $\mathrm{Hu}$ et al. (2012) reported the public perception that organic certified foods had turned into a large-scale commercial industry owned by few corporations. These findings are consistent with USDA reports that showed an increasing value of organic foods sold by fewer operations (USDA-ERS, 2016). Farmers' philosophy of organic agriculture may be incompatible with the large-scale production, consolidation, and commercialization of organic foods in the United States. This is especially true as the world's largest food retailers, including big box stores, have entered the U.S. organic foods market (Dimitri and Oberholtzer, 2009). Thus, the industrialization of organic foods may be driving farmers to opt out from certification. Our results did not show that supporting the philosophy of organic farming had an effect on the decision to decertify. This may be because most decertified farmers remained farming organically; thus, their agricultural practices were aligned with the organic movement.

Other perceptions regarding the organic markets and the certification process appeared to affect the decision to decertify by organic farmers. Farmers were more likely to decertify if they perceived that loss of freedom, paperwork, cost of certification, interaction with the certifier, and lack of information were barriers to remain certified. It seems that the requirements embedded in the certification process were detrimental to the decision to remain certified. The probability to decertify decreased among farmers perceiving that organic markets were risky or reliable. We expect that as farmers became more aware of the threats of marketing organic foods, they learned to overcome these risks by implementing management strategies.

Researchers, policymakers, and industry leaders can use this information to develop incentives and initiatives to lower decertification rates, which can greatly influence the long-term sustainability of the organic industry. Farmers reported that the certification process is detrimental to both the decision to certify (Torres et al., 2016) and remain certified. The fact that the certification process was a barrier to remain certified in our study suggests the need to provide farmers with knowledge and training that decreases the risk and uncertainty of being certified. Information regarding market prices, access to markets, and the certification process seemed to be key to the success of organic certified farmers. One possible limitation of the study is the fact that the dataset did not include operations that decertified and exited farming. Future research should look at the decision to decertify at several points of time and include farmers who stopped farming.

\section{Literature Cited}

Blank, S.C. and G.D. Thompson. 2004. Can/ should/will a niche become the norm? Organic agriculture's short past and long future. Cont. Econ. Pol. 22(4):483-503.

Brown, C. and S. Miller. 2008. The impacts of local markets: A review of research on farmers markets and community supported agriculture (CSA). Amer. J. Agr. Econ. 90(5):1298-1302.

Burton, M., D. Rigby, and T. Young. 1999. Analysis of the determinants of adoption of organic horticultural techniques in the UK. J. Agr. Econ. 50(1):47-63.

Constance, D.H. and J.Y. Choi. 2010. Overcoming the barriers to organic adoption in the United States: A look at pragmatic conventional producers in Texas. Sustainability 2(1):163-188.

Darnhofer, I., W. Schneeberger, and B. Freyer. 2005. Converting or not converting to organic farming in Austria: Farmer types and their rationale. Agr. Human Values 22(1):39-52.

Dillman, D.A., J.D. Smyth, and L.M. Christian. 2014. Internet, phone, mail, and mixed-mode surveys: The tailored design method. 3rd ed. Wiley, New York, NY.

Dimitri, C. 2012. Use of local markets by organic producers. Amer. J. Agr. Econ. 94(2):301-306.

Dimitri, C. and C. Greene. 2002. Recent growth patterns in the US organic foods market. USDA-ERS Econ. Info. Bul. 55.

Dimitri, C. and L. Oberholtzer. 2008. The U.S. organic handling sector: Baseline findings of the nationwide survey of manufacturers, processors, and distributors. USDA-ERS Econ. Info. Bul. 36.

Dimitri, C. and L. Oberholtzer. 2009. Marketing US organic foods: Recent trends from farms to consumers. USDA-ERS Econ. Info. Bul. 58.

Etmanski, C. 2012. A critical race and class analysis of learning in the organic farming movement. Austral. J. Adult Learn. 52(3):484-506.

Greene, C.R., C. Dimitri, B.H. Lin, W.D. McBride, L. Oberholtzer, and T.A. Smith. 2009. Emerging issues in the US organic industry. USDAERS Econ. Info. Bul. 55.

Guptill, A. 2009. Exploring the conventionalization of organic dairy: Trends and counter-trends in upstate New York. Agr. Human Values 26(1-2):29-42. 
Hanson, J., R. Dismukes, W. Chambers, C. Greene, and A. Kremen. 2004. Risk and risk management in organic agriculture: Views of organic farmers. Renew. Agr. Food Syst. 19(4):218-227.

Hinrichs, C.C. 2000. Embeddedness and local food systems: Notes on two types of direct agricultural market. J. Rural Stud. 16(3):295-303.

Holt, G. and M. Reed. 2006. Sociological perspectives of organic agriculture: From pioneer to policy. CAB Intl, Wallingford, UK.

Hu, W., M.T. Batte, T. Woods, and S. Ernst. 2012. Consumer preferences for local production and other value-added label claims for a processed food product. Eur. Rev. Agr. Econ. 39(3): 489-510.

Kim, J.O. and C.W. Mueller. 1978. Factor analysis: Statistical methods and practical issues. Sage, Newbury Park, CA.

Klonsky, K. 2000. Forces impacting the production of organic foods. Agr. Human Values 17(3): 233-243.

Klonsky, K. and M.D. Smith. 2002. Entry and exit in California's organic farming sector. In: D.C. Hall and L.J. Moffit (eds.). Economics of pesticides, sustainable food production, and organic food markets. Elsevier Science, Amsterdam, The Netherlands.

Läpple, D. 2010. Adoption and abandonment of organic farming: An empirical investigation of the Irish drystock sector. J. Agr. Econ. 61(3): 697-714.

Mzoughi, N. 2011. Farmers adoption of integrated crop protection and organic farming: Do moral and social concerns matter? Ecol. Econ. 70(8): 1536-1545.

Padel, S. 2001. Conversion to organic farming: A typical example of the diffusion of an innovation? Sociol. Rural. 41(1):40-61.
Parrott, N., J.E. Olesen, and H. Høgh-Jensen. 2006. Certified and noncertified organic farming in the developing world. In: N. Halberg, H.F. Alroe, M.T. Knudsen, and E.S. Kristensen (eds.). Gobal development of organic agriculture: Challenges and prospects. CABI Publ., Wallingford, UK.

Sahm, H., J. Sanders, H. Nieberg, G. Behrens, H. Kuhnert, R. Strohm, and U. Hamm. 2013. Reversion from organic to conventional agriculture: A review. Renew. Agr. Food Syst. 28(3):263-275.

Sierra, L., K. Klonsky, R. Strochlic, S. Brodt, and R. Molinar. 2008. Factors associated with deregistration among organic farmers in California. California Inst. Rural Studies, Davis, CA.

Strochlic, R. and L. Sierra. 2007. Conventional, mixed and deregistered organic farmers: Entry barriers and reasons for exiting organic production in California. California Inst. Rural Studies, Davis, CA.

Thilmany, D., C.A. Bond, and J.K. Bond. 2008 Going local: Exploring consumer behavior and motivations for direct food purchases. Amer. J. Agr. Econ. 90(5):1303-1309.

Torres, A.P., M.I. Marshall, C.E. Alexander, and M.S. Delgado. 2016. Are local market relationships undermining organic fruit and vegetable certification? A bivariate probit analysis. Agr. Econ. 48:1-9.

USDA. 2015. Organic farming: Results from the 2014 organic survey. 25 Jan. 2017. <https:// agcensus.usda.gov/Publications/2012/Online_ Resources/Highlights/Organics/2014_Organic_ Survey_Highlights.pdf $>$.

USDA. 2016. Statement from agriculture secretary Tom Vilsack on the organic trade association report [Press release]. 30 Aug. 2017. <https:// www.usda.gov/media/press-releases/2016/05/ 19/statement-agriculture-secretary-tom-vilsackorganic-trade $>$.

USDA-ERS. 2016. Organic prices. 30 Aug. 2017. $<$ https://www.ers.usda.gov/webdocs/DataFiles/ Organic_Prices_18001/Vegetables.xls?v=41719>.

USDA-NASS. 2016. Certified organic survey (2015 summary). 30 Aug. 2017. < http://usda. mannlib.cornell.edu/usda/nass/OrganicProduction//2010s/2016/OrganicProduction-09-15-2016. pdf $>$.

Veldstra, M.D., C.E. Alexander, and M.I. Marshall. 2014. To certify or not to certify? Separating the organic production and certification decisions. Food Policy 49:429-436.

Walz, E. 2004. Fourth national organic farmers' survey. Organic Farming Research Foundation. 30 Aug. 2017. <http://ofrf.org/sites/ofrf.org/ files/docs/pdf/4thsurvey_results.pdf $>$.

Ward, R., L. Hunnicutt, and J. Keith. 2004. If you can't trust the farmer, who can you trust? The effect of certification types on purchases of organic produce. Intl. Food Agribus. Mgt. Rev. 7(1):60-77.

Whatmore, S. 2016. Farming women: Gender, work and family enterprise. Macmillan, London, UK.

Wiegel, W.J. 2009. Adoption of organic farming systems in Missouri. Univ. Missouri, Columbia, M.S. Thesis.

Wooldridge, J.M. 2010. Econometric analysis of cross section and panel data. 2nd ed. The MIT Press, Cambridge, MA.

York, M., M.H. Lau, R.D. Hanagriff, and D.H. Constance. 2007. Identifying barriers to entry into the organic market and possible strategies to increase the likelihood of success for potential organic producers. Final report. Sam Houston State Univ., Huntsville, TX. 